\title{
TERMELÉSÜTEMEZÉSI ÉS KÉSZLETGAZDÁLKODÁSI FELADATOK INTEGRÁLT MEGOLDÁSA
}

\author{
Kulcsárné Forrai Mónika \\ egyetemi docens, Miskolci Egyetem, Informatikai Intézet, Alkalmazott Informatikai Intézeti Tanszék \\ 3515 Miskolc, Miskolc-Egyetemváros, e-mail: aitkfm@uni-miskolc.hu \\ Kulcsár Gyula \\ egyetemi docens, Miskolci Egyetem, Informatikai Intézet, Alkalmazott Informatikai Intézeti Tanszék \\ 3515 Miskolc, Miskolc-Egyetemváros, e-mail: iitkgy@uni-miskolc.hu
}

\begin{abstract}
Absztrakt
A cikk bemutatja egy jármüipari összetett termelésprogramozási feladat megoldását. A feladat jellegzetessége, hogy többféle osztott hozzáférésü eröforrást kell egyidejüleg kiosztani és párhozamos végrehajtású munkákat kell ütemezni szigorú határidös rendelések teljesitése érdekében. Ezen túlmenően az ütemezés és a készletgazdálkodás egy integrált feladatát kell megoldani. A cikk összefoglalja a vizsgált feladat legfontosabb jellemzőit és a kifejlesztett megoldási módszer koncepcióját
\end{abstract}

Kulcsszavak: ütemezés, készletgazdálkodás, termelés, kereső algoritmus, többcélú optimalizálás

\section{Abstract}

The paper describes the solution of a complex production fine scheduling problem of the automotive industry. The main characteristic of the problem is that different types of shared resources have to be allocated simultaneously, and multi-processing tasks have to be scheduled to satisfy production orders with strict due dates. In addition, it is needed to solve an integrated task of scheduling and inventory control. The paper presents the main features of the problem and the approach of the developed solving method.

Keywords: scheduling, inventory control, production, search algorithm, multi-objective optimization

\section{Bevezetés}

A piaci környezet arra készteti a termelő vállalatokat, hogy folyamatosan fejlesszék versenyképességüket. A növekvő vevői igények a termelési hatékonyság és a szállítókészség fokozását követelik meg. Ugyanakkor költséghatékony müködtetés érdekében a készletek alacsony szinten tartására, az erőforrások magas fokú kihasználtságára és a járulékos költségek csökkentésére kell törekedni.

A termeléstervezés és aggregált ütemezés eredményei általában közvetlenül nem alkalmazhatók a gyártás operatív irányítására, mivel az elkészített tervek összevontan kezelt erőforrásokra vonatkozó durva megoldásokat alkotnak. Viszont a termelésprogramozás (detailed scheduling) minden fontos részletre kiterjedő kellően pontos végrehajtási finomprogramokat tud készíteni rövid időhorizontra. Az ilyen termelési finomprogramok generálása érdekében a komplex döntéshozatalnak ki kell terjednie a 
termelés főfolyamatain túl (gyártás, szerelés) a legfontosabb kapcsolódó mellék (pl. logisztikai, készletgazdálkodási) és segéd (pl. szerszámellátási) folyamatokra is.

Cikkünkben bemutatunk egy új integrált termelésütemezési és készletgazdálkodási modellt, amelyet egy konkrét jármüipari gyártórendszer számára fejlesztettünk ki.

\section{A vizsgált termelési folyamat}

A vizsgált jármüipari gyártóműhelyben üléselemeket készítenek különböző márkájú és típusú személyautókhoz. A vevők által generált, adott terméktípusra és darabszámra vonatkozó rendeléseket t szoros határidőre kell teljesíteni.

Az üzem az üléselemek előállítását körpálya kialakítású gyártórendszerekben (pályákon) valósítja meg. Adott terméktípus általában több pályán is gyártható. Minden egyes pálya adott számú teljes ciklust tud elvégezni egy müszakban, továbbá adott számú csatlakoztatási ponttal (pozícióval) rendelkezik. Egy pozícióhoz egy formahordozó csatlakoztatható, amely kialakítástól függően egyvagy kétoldalas lehet. A formahordozó bal és jobb oldalára szerszámok (formák) rögzíthetők a gyártástechnológia által meghatározott szabályok szerint.

Szigorú szabályok írják elö, hogy milyen terméket, melyik pályán, milyen pozícióban, milyen típusú formahordozón, melyik oldalon és milyen más termékkel együtt lehet gyártani.

A pályák önállóan definiált müszakrend szerint müködnek. Minden egyes müszakban pályánként előírt darabszámú pozícióban végezhető el csere. Egy csere alapegysége egy formahordozóból és a hozzá kapcsolódó formából (vagy formákból) álló konfiguráció. Adott konfiguráció levétele egy aktív pozícióból és egy előkészített másik konfiguráció felhelyezése ugyanabba a pozícióba jelent egy teljes cserét. A termelésirányítás szempontjából a csere jelenti az alapvető beavatkozási lehetőséget.

A pályák kialakítása különböző, ezáltal az egy müszakban megtehető teljes ciklusok száma is eltérő. A termékek gyártásához rendszerint több, eltérő darabszámú forma és formahordozó áll rendelkezésre.

A vázolt termelési folyamat finomprogramozása során a cél az, hogy a szigorú korlátozások betartása mellett a termelés-menedzsment által támasztott általános kritériumok tekintetében a lehető legjobb teljesítményt érjük el.

A feladat megoldásával kapcsolatban a legfontosabb elvárások a következők:

1. A gyártási rendelések teljesítése csúszások nélkül valósuljon meg.

2. A gyártás a lehető legkevesebb átállással (konfiguráció előkészítéssel és cserével) valósuljon meg.

3. El kell kerülni a túl nagy készletek felhalmozását.

4. Biztosítani kell a terméktípusonként (cikkszámonként) külön-külön előírt minimális készletszintet.

5. A gyártósorok (pályák) kihasználtságát maximalizálni kell.

A vázolt feladat sajátosságai miatt nem sorolható be közvetlenül egyik ismert ütemezési feladatkategóriába sem. A termelésütemezés és a készletgazdálkodás egy kombinált új feladatához jutottunk.

\section{A kidolgozott megoldási módszer}

A szakirodalomban számos könyv és szakcikk foglalkozik az ütemezési modellekkel és módszerekkel pl. [1-4], azonban a vizsgált probléma sajátosságaihoz pontosan illeszkedő modellt nem találtunk. 
A termelésprogramozási feladat megoldása során az ismert gyártási rendelések teljesítését kell biztosítani. Ehhez a termékek gyártására alkalmas pályák (gyártósorok), formahordozók és formák lekötését (terhelését) és az elvégzendő konfigurációk-cserék időpontjait kell úgy megtervezni, hogy a szigorú korlátozások megsértése nélkül a megfogalmazott célok megvalósuljanak. A probléma megoldását a termelési finomprogram adja meg, amely elöírja, hogy melyik gyártósoron, melyik pozícióban, melyik müszakban (mikor), milyen konfigurációt kell kicserélni, és azzal milyen terméket vagy termékeket kell gyártani.

Mivel a vizsgált üzem terméktípusonkénti termelési intenzitása viszonylag lassan módosítható a vázolt gyártástechnológiai korlátozások miatt, így a változatos megrendelések kiszolgálása igen komoly feladatot jelent. A beérkezett vevői rendelések alapján a finomprogram jellemzően egy-két hétre előre készíthető el. A termelő rendszer „lomhasága” miatt szükséges a különböző terméktípusokra egyedileg kalibrált készletszintet fenntartani. Az adott terméktípusra vonatkozó mindenkori kívánt optimális készletszintet egy alsó és egy felső határérték definiálásával célszerü elöírni.

A bemutatott összetett optimalizálási feladat NP-nehéz, ezért a kutatás-fejlesztés során alapvetően heurisztikus és tudás-intenzív keresési technikákra koncentráltunk. Korábban sikeresen alkalmazott modelljeinkböl indultunk ki $[5,6]$.

A feladat döntési változóinak értékét - melyeket a termelési finomprogram tartalmaz - egy többoperátoros és többcélú kereső algoritmus állítja be. Ez iteratívan módosítja a választott bázis megoldást. Konzisztens változtatásokkal új megoldás-változatokat készít és a legjobbat bázisnak tekintve tovább módosítja lépésről lépésre haladva.

A kereső algoritmusban többféle módosító operátort alkalmazunk, melyek a gyártósorok pozícióiban az adott időhorizonton aktívan használt formahordozókra és formákra vonatkozó döntési változókat módosítják.

A módosítás célja, hogy a hiánnyal rendelkező terméktípus gyártását elősegítse és az esetleg többlettel rendelkező terméktípust visszafogja. Adott gyártósoron egy kiválasztott termék gyártásának beütemezése azt jelenti, hogy kiválasztásra kerül egy olyan müszak, amelyben az elöírt csereszámkorlát megsértése nélkül egy új kedvező hatást eredményező csere végrehajtható.

$\mathrm{Az}$ adott megoldás-változathoz tartozó gyártott termékmennyiségek és készletek időbeli alakulásának számítását egy szimulációs eljárás végzi el. Ez az algoritmus figyelembe veszi a korábban ismertetett korlátozásokat és müködési jellemzőket (pl. a gyártósorok müszakbeosztását, a termelési intenzitásokat, a kiszállítási időpontokat stb.).

A szimuláció által szolgáltatott értékek felhasználásával egy értékelő komponens kiszámítja a vizsgált termelési finomprogramra (megoldás-változatra) vonatkozó teljesítménymutatók aktuális értékeit. A gyártásirányítás által támasztott igényeket a modellben a következő célfüggvények együttes kompromisszumos minimalizálása fejezi ki:

- $f_{1}$ : Maximális termékhiány $[\mathrm{db}]$.

- $f_{2}$ : A termékhiány összege $[\mathrm{db}]$.

- $f_{3}$ : A csúszó gyártási megrendelések száma.

- $f_{4}$ : Az átállítások (cserék) száma.

- $f_{5}$ : A cserék maximális száma egy müszakban.

- $f_{6}$ : A többlettel záró terméktípusok száma.

- $f_{7}$ : A terméktöbbletek összege $[\mathrm{db}]$.

- $f_{8}$ : A maximális termékhiány az időszak végén [db].

- $f_{9}$ : A termékhiány összege az időszak végén $[\mathrm{db}]$. 
- $f_{10}$ : A csúszó rendelések prioritásainak összege.

- $f_{11}$ : A csúszó rendelések maximális prioritása.

- $f_{12}$ : A csúszó terméktípusok száma.

- $f_{13}$ : A maximális termékhiány (nullához képest) [db].

- $f_{14}$ : A termékhiány összege (nullához képest) [db].

- $f_{15}$ : A maximális csúszás [müszak].

- $f_{16}$ : A csúszások összege [müszak].

- $f_{17}$ : A konfiguráció-előkészítések száma.

- $f_{18}$ : Nem használt pályakapacitás [termékgyártási alapegység].

A modellben több új készletre vonatkozó teljesítménymutatót használunk célfüggvényként. Ezek számításának lényege az, hogy a gyártott mennyiségeket és a kiszállított mennyiségeket az idő függvényében összevonva kezeljük, így bármely időpontban számszerüsíthető az aktuális készletszintérték minden egyes terméktípus esetében. Az aktuális értékek felhasználásával az adott referencia alsó és felső határokhoz viszonyított hiány vagy többlet egyszerüen számítható.

Ezt a koncepciót alkalmazva a rendelések teljesítésének csúszása szintén egyszerüen számítható a készlet-idő diagram alapján. Az előírt határidő pillanatában az aktuális készletszint és a rendelt mennyiség különbségeként adódó elöjeles érték mutatja a hiányt (negatív érték) vagy a többletet (pozitív érték). A rendelés csúszása azt az időtartamot jelenti, amely az előírt határidő és a tényleges teljesítés között eltelik.

A kifejlesztett integrált termelésprogramozási modell lényeges új elemei közé tartozik az időben korlátozottan rendelkezésre álló gyártási kapacitások menedzselése, az osztott hozzáférésủ erőforrások irányítása, a gyártás-előkészítési feladatok ütemezése, a készletszintek terméktípusonkénti sávos optimalizálása és a célfüggvények körének jelentős bővítése.

\section{4. Összefoglalás}

A cikkben összefoglalt kutatómunka során egy jármüipari alkatrészgyártó rendszer speciális termelésprogramozási feladatának megoldási módszerét dolgoztuk ki. A modell az igény szerinti rugalmas gyártás prediktív tervezésére alkalmas, amely magába foglalja a munkák erőforrásokhoz rendelését, a végrehajtás ütemezését és az osztott hozzáférésü erőforrások menedzselését, valamint a terméktípusok készletszintjének irányítását.

A gyakorlatban valós körülmények között elvégzett elemzések azt mutatták, hogy a kidolgozott módszerek alapján implementált termelésprogramozó szoftverünk képes hatékonyan megoldani a feladatot.

\section{Köszönetnyilvánítás}

A kutató munka a Miskolci Egyetem stratégiai kutatási területén müködő Mechatronikai és Logisztikai Kiválósági Központ keretében valósult meg. 


\section{Irodalom}

[1] Allahverdi, A., Ng, C. T., Cheng, T. C. E., Kovalyov, M. Y.: A survey of scheduling problems with setup times or costs, European Journal of Operational Research 2008, 187: 985-1032. https://doi.org/10.1016/j.ejor.2006.06.060

[2] Brucker, P.: Scheduling Algorithms, E5th ed, Springer-Verlag Berlin Heidelberg, 2007, ISBN 978-3-540-69515-8.

[3] Gharbi, A., Haouari, M.: Optimal parallel machines scheduling with availability constraints, Discrete Applied Mathematics 2005, 148:63-87. https://doi.org/10.1016/j.dam.2004.12.003

[4] Kaabi, J., Harrath, Y.: E A survey of parallel machine scheduling under availability constraints, International Journal of Computer and Information Technology 2014, 3(2):238-245.

[5] Kulcsár, G.: Ütemezési modell és heurisztikus módszerek az igény szerinti tömeggyártás finomprogramozásának támogatására, E PhD értekezés, Miskolci Egyetem, 2007.

[6] Kulcsár G., Kulcsárné Forrai M.: Detailed Production Scheduling Based on Multi-Objective Search and Simulation, Production Systems and Information Engineering 2013, 6:41-56. 